\title{
THE USE OF SEM MORPHOSCOPY IN RESEARCHING THE LITHO-PEDOGENETIC ENVIRONMENTS EVOLUTION OF LATE PLEISTOCENE AND HOLOCENE
}

\author{
MAREK DEGÓRSKI*, ALOJZY KOWALKOWSKI** \\ * Department of Geoecology and Climatology, \\ Institute of Geography and Spatial Organization, Polish Academy of Sciences, \\ Twarda 51/55, 00-818 Warszawa, Poland \\ E-mail: m.degor@twarda.pan.pl \\ ** Świętokrzyska Academy, \\ Faculty of Mathematics and Natural Sciences, Institute of Geography, \\ Świętokrzyska 15, 25-406 Kielce, Poland
}

\begin{abstract}
Ultramorphoscopic analysis offers one way of gaining an insight into temporal and spatial changes that have taken place in the environment. The underlying basis here is a system of classified features; processes of physical, chemical and biological weathering; and processes of transport through different environments. It is the aim of this article to present the use of morphoscopic SEM studies of podsolic soils from different parts of central and northern Europe in reconstructing the way litho- and pedogenetic conditions evolved in the Late Pleistocene and Holocene. By drawing on the research carried out, it has been possible to point to certain indicative morphoscopic features of quartz grains that are characteristic for defined morphogenic environments.
\end{abstract}

Key words: scanning electron microscope (SEM), quartz grain, sedimentation environment, podsolic soils, central and northern Europe

\section{INTRODUCTION}

The natural environment is subject to constant change arising out of altering external conditioning, be this caused by energy from the Earth's interior or energy from the cosmos, or - since humankind first appeared on the Earth - brought about thanks to human impacts. Asymmetrical and non-linear natural processes ongoing in the environment and of differing durations and intensities in different geographical regions give rise to changes of short (i.a. seasonal) duration, to long-term changes (taking whole eras or ages), and to sudden changes reflecting extreme phenomena. Through the impact of such changes on the entire natural system, a shaping of that system's spatial structure takes place, this having defined properties and features.

In cognitive investigations of the courses to mechanisms and processes shaping the environment (and in both the geological and historical time horizons), it is the simplest measures and indicators that are invariably being sought out. The assumption underpinning this activity is that it will prove possible to elucidate instrumentation that will be at one and the same time a precise estimator allowing for assessment of the structural and functional regularities ongoing dynamically in space, and a facilitator allowing for the ob- 
tainment of the broadest reliable information on the research object that the environment in the course of its spatial evolution represents.

All that said, it is necessary to stress that the sheer complexity and diversity of morphogenetic and pedogenetic processes in our planet's natural system are such as to make analysis of developmental changes ongoing in it a very difficult matter. Thus far, our recognition of the rules applying more widely across space is inevitably more of an understanding of the order humankind seeks to impose on reality so that that reality might be understood more fully. It is thus more than possible that what we understand about the world is not necessarily its ultimate truth (Degórski, 2004).

One way familiarity may be gained with the changes present spatially and/or temporally in the environment - especially when it comes to interpreting the development of palaeoenvironments - is ultramorphoscopic analysis. As one of the basic diagnostics tools, this makes use of a scanning electron microscope to study mainly quartz sand. What underpins contemporary ultramorphoscopic analysis is a system of classified ultramorphoscopic features and processes of physical, chemical and biological weathering, as well as of transport through different environments on the Earth's surface that change both spatially and temporally. The objects of study are in fact the morphological relief forms, shape and matt or gloss nature of the grain surface as visible in scanning electron microscopy (SEM) micrographs. The data obtained using this analysis serve in the determination of the sequence of changing geomorphological and pedogenetic conditioning affecting spatially and temporally the development of the environment, above all past and present morphopedogenetic landscapes (Kowalkowski and Degórski, 2008).

\section{RESEARCH OBJECTIVES AND OBJECTS}

This article has sought to consider the opportunities for using data from SEM morphoscopic studies of the surfaces of grains of quartz sand present in soil substrata and the genetic horizons of soils generated from them displaying features of podsolisation, with a view to insight being gained into the evolution of certain morphogenetic elements of the land surface in Late Holocene and Pleistocene environments. With this aim in mind, use was made of data from research carried out in northern and central Europe in the years 2004-2008, in five areas whose general characteristics are as follows:

1. Northern Finnish Lapland (Kevo 7

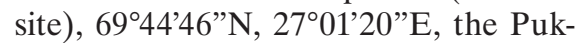
salskaidi granulite massif at $210 \mathrm{~m}$ a.s.1., periglacial cryogenic weathered material from the Holocene in situ with grain-size of clayey skeletal sand, with eo- and meso-Holocene rusty podsolic soil of tundra origin with a profile (where the depths of the bases of each horizon are given in $\mathrm{cm}$ ): L (1) - Ofh (8) - Ehl (12) - BvtBhfe (15) - Bvt (25-30) $-\mathrm{Bv}(55)-\mathrm{CBv}$.

2. The southern Baltic Shore, Poland's Hel Peninsula (Jurata 10 site), 5462'42”N, 18 72'12”'E, yellow coastal berm 3-4 m a.s.l., loose meso/neo-Holocene sands, medium- or fine-grained reflecting marine accumulation and with shallow aeolian cover on deep beach sands, soil an extraperiglacial humus-iron podsol with a profile: L (2) - Ofh (10) - E2 (21) - Ahe (26) - Eh1 (31) - Bhfe (36) - Bfe (60) - Cfe (92) - Cgg.

3. Rugia Island (Germany), Schaabe Bar (Glowe 15 site), 5437'31'N, 1330'09'E, brown coastal berm $2.5 \mathrm{~m}$ a.s.l., Neo-Holocene extraperiglacial loose medium- or fine-grained sand with single rounded black firestones reflecting marine accumulation, soil a neo-Holocene gley podsol with the profile: L (2) - Ofh (10) - E2 (21) - EhBhfe (5) - Bhfeorgg (100) - Cfeggor.

4. Podlasie-Byelorussia Plateau (Białowieża 4 site), 52³7'54”N, 2330'45”E, $171 \mathrm{~m}$ a.s.1., deluvial moraine sand from the Odra Glaciation superimposed on deep glaciofluvial sands of the Vistula Glaciation, young-glacial periglacial 
plain with rusty, weakly-podsolic soil of the profile: L (1) - Ofh (2) - AhE (10) - vBfe (20) - Bv1 (30) - Bv2 (55) - CBv (95) - D.

5. Karkonosze Mountains of Poland (Równia pod Śnieżką site), 5044'29”N, $15^{\circ} 42^{\prime} 38^{\prime \prime E}, 1423 \mathrm{~m}$ a.s.l., Pleistocene-Holocene proglacial and periglacial weathered debris in situ on a granite massif on Palaeogenic planation, periglacial clayey sands and skeletal sandy clays with frost-induced pedogenetic segregation, soil an old-glacial/eo-Holocene rusty-podsolic, polygonal ex-tundra soil of profile: L (2) - OAhe (9) - Ehl (12) - BvlBhfe (26) - BvtBfe (32) - Bvt (60) - CBvt (68) - Rg.

In-depth discussion and sedimentological, geomorphological and pedological analysis of the above study areas is to be found in the relevant monograph by $\mathrm{M}$. Degórski et al., 2012.

\section{THE BASIC METHODOLOGICAL PARADIGMS UNDERPINNING MORPHOSCOPIC INTERPRETATION}

Understanding what led to the emergence of the sets of morphological features present together on the surfaces of grains of quartz sand is what may allow for the reconstruction of the ancient and contemporary conditions present in the geographical environment as the genesis of sediments and soils took place. The method also provides for a more precise defining of the processes thanks to which a given soil first arose, and was then transformed into horizontally-profiled configurations of genetic horizons of defined morphological features and physical, physico-chemical and chemical properties (Krinsley and Doornkamp, 1973; Bull, 1984; Kowalkowski and Degórski, 2008). The introduction into 1960 s research practice of ultramorphoscopic apparatus, then transmission electron microscopy (TEM) and scanning electron microscopy (SEM) led to an intensification of research on the surface relief of grains of quartz sand, as well as many other primary or secondary rock-forming minerals from different morphogenetic sedimentation environments (Mycielska-Dowgiałło, 1963, 1980a, b; Kozarski, 1972, Klatkowa, 1976, Kowalkowski and Mycielska-Dowgiałło, 1980, 1983, 1988; Bednarek, 1988, 1991, Mahaney, 1995; Mahaney and Kalm, 1995). This was a phase of the intensive search for feature identifiers. The first conceptual studies appeared in the late 1970s, attention being paid to the fact that identification of the genesis of a given sediment could be based on, not one feature on the surface of a quartz grain but a combination of several (Margolis and Kenneth 1970). In the same period, the summary of the different classifications by R. Higgs (1979) involved the identification of 30 variants to the forms of grain relief, among which some 22 were regarded as especially characteristic and diagnostic of given environments. At the same time, Higgs stressed that identical forms of relief of individual grains could arise in different environments.

The first decade of the $21^{\text {st }}$ century saw several publications appear (e.g. Schwamborn et al., 2006; Hoch and Woronko, 2007, Rose and Hart, 2008, Woronko and Ostrowska, 2009; Woronko and Bujak, 2010; Traczyk and Woronko, 2010), discussing the insights into the conditions under which weathered waste, sediments and morphogenetic forms arose in glacial, periglacial and glaciofluvial environments that were capable of being gained through the study of morphoscopic features visible under SEM, and supplying valuable data on pedogenetic processes. Of particular significance to further research was the 2002 Atlas of Sand Grain Surface Textures and Applications by William C. Mahaney.

Thus, the methodology for the morphoscopic interpretation of grains of quartz sand by means of the assessment of the system of geomorphopedogenetic processes is founded upon two directions in which it is possible to proceed, i.e. the recognition of sets of features that arise over time in the system of sand grain surface-modification 


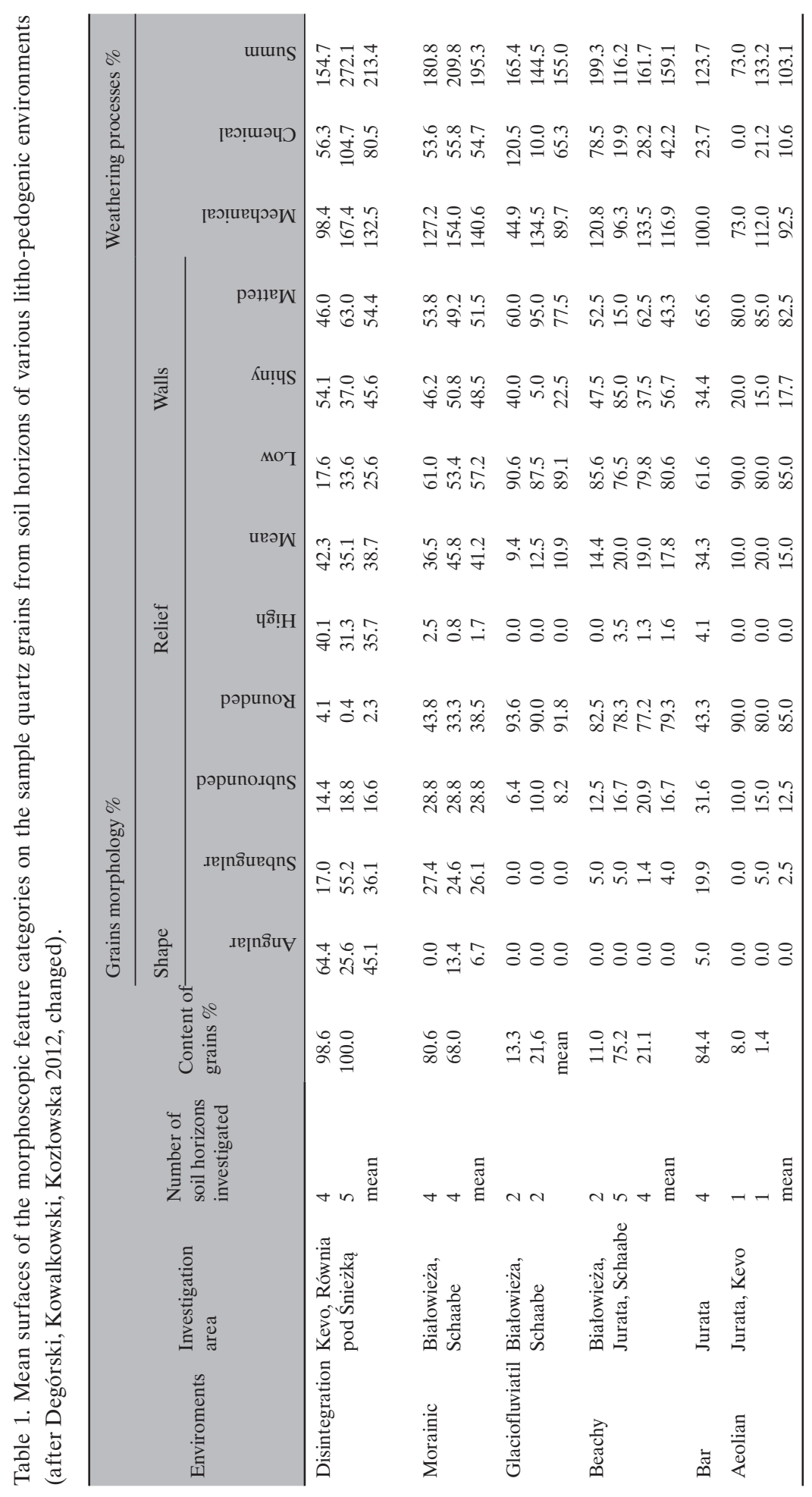


processes, and the interpretation of the causes underpinning their appearance, in line with the theory of the evolutionary consideration of natural phenomena proposed by R. Riedel (2000). Here account needs to be taken of the fact that the surfaces of grains of quartz sand retain and accumulate in a permanent way several generations of morphoscopic features that depend on the courses of the inseparable processes of lithomorphogenesis and pedogenesis. It is for this reason that the total area of all these features often exceeds $100 \%$ of the sand-grain surface.

The research presented here was carried out in line with the standards set out for SEM analysis methodology. The starting point for the analyses was the identification for each object of representative soil profiles, for each of which 30 grains of quartz of diameter $0.5-0.8 \mathrm{~mm}$ were selected in each different genetic horizon of a given sample. This was then followed by the study - following appropriate preparation - of the morphoscopic features recordable on the surface of mineral grains using the modified method of P.A. Bull (1984, 1986). Three main categories of ultramorphoscopic features on SEM-micrographs were identified with categories and sub-categories, i.e. (1) - the morphology of grain surfaces, with a distinction drawn between categories of relief, shape, and lustre (matted or shiny), with 9 sub-features visible at c. $100 \mathrm{x}$ magnification; (2) - a category of features of mechanical weathering, with sub-categories of incision, chipping, splitting, exfoliation, fracturing, decay and dehydration, with 39 features visible at magnifications in excess of 1000x; (3) - a category of features of chemical weathering, with sub-categories relating to encrustation and etching, with 22 sub-features discernible at magnifications over 2000x. On the basis of a characterisation of sets of morphoscopic features, covering defined surface areas of grains estimated in percentage terms, of weathered origin (in situ), or else of morainic, glaciofluvial, beach, aeolian or coastal berm origin (as presented in Table 1).

\section{OUTLINE OF MORE IMPORTANT RESULTS}

\section{THE ENVIRONMENT OF THE WEATHERED ROCK MATERIAL}

Comparison of the diagnostic features present on the surfaces of sand grains from the Równia pod Śnieżką research site in the Sudetic Mountains and the Kevo area of Finnish Lapland shows a uniformity associated with similarity of cold-climate environment, as diversified by sequences of soil horizons generated from acid, frost-weathering-generated debris from the Holocene, but irrespective of their different Late Pleistocene or Eo-Holocene age. The diagnostic feature dominant at Kevo is the angular shape, with high and moderate relief on the quartz grain surface which may be both shiny (Fig. 1) or matt (Fig. 2). In contrast, on the old planation below Śnieżka, the cryogenic waste material deriving from granite rocks in the Pleistocene comprises angular and semi-angular grains of more diverse relief that may be high, mean or low, with sharp edges and corners arising out of advanced mechanical weathering. The dominant spherical shape that leaves them reminiscent of sharp-edged spheres, with a prevalence of matted - as opposed to shiny - surface lustre due to pedogenetic weathering thereof that is much stronger here than at Kevo (Figs. 3 and 4 ).

It is true that, in the environment in question, minerals being affected more readily by chemical weathering, e.g. feldspars, have preserved relict features of angular shape with high or mean relief reflecting mechanical frost weathering. However, their surfaces generated by intensive spongiform (biochemical) pedogenetic digestion and encrustation with superimposed pelitic scalling and lamellar breakages. Nevertheless, they were subject to complete matting, with a change in grain shape to rounded or subrounded with mean or low and sharp-walled relief (Figs. 5 and 6).

On the surfaces of the grains studied from soil horizons at Równia pod Śnieżką (where a tundra environment prevailed for long periods in the Pleistocene, as well as 


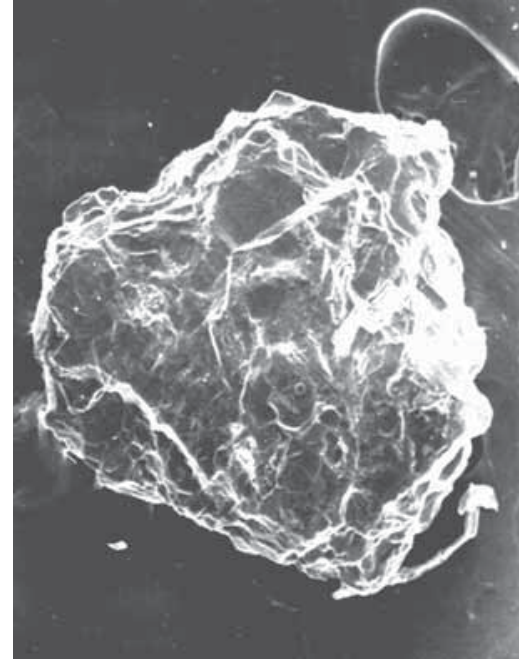

Figure 1. Spheroidal angular quartz grain with high and average sharp-edged relief and multidirectional block, granular and lamellar scalling and cryogenic fractures, and small matt-surfaced caverns reflecting selective chemical etching (magnification $72 \mathrm{x}, \mathrm{BvC}$ horizon, depth 25-35 cm, Kevo, Holocene ridge planation).

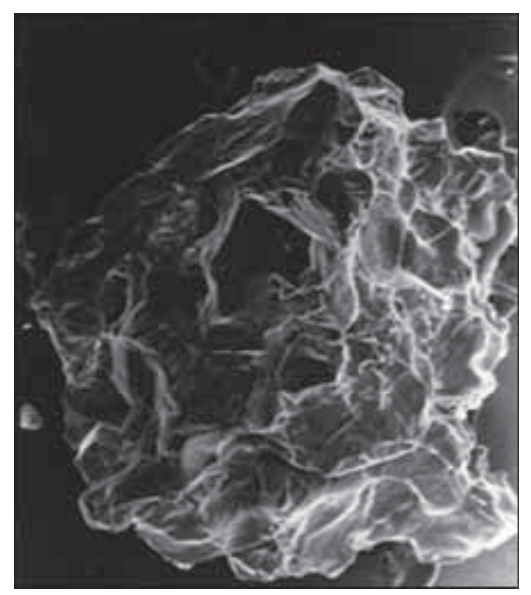

Figure 3. A spheroidal angular grain of quartz with moderate or high relief and sharp-edged and shiny conchoidal walls characterising granular and lamellar mechanical weathering (magnification 94x, Ees horizon, depth 8-10 cm, Równia pod Śnieżką, relict periglacial planation).

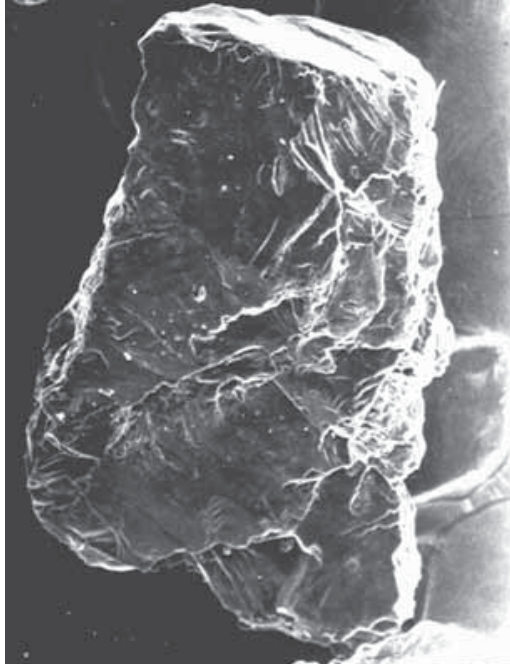

Figure 2. Angular grain of quartz with high cryogenic relief or large and small conchoidals, or else high and low relief of multidirectional

blocky, granular and sharp-edged lamellar fractures with shiny surfaces, grain edges with low relief of fine lamellar and crevassed fractures (magnification 100x, Ees horizon, depth 8-10 $\mathrm{cm}$, Kevo, Holocene periglacial ridge planation).

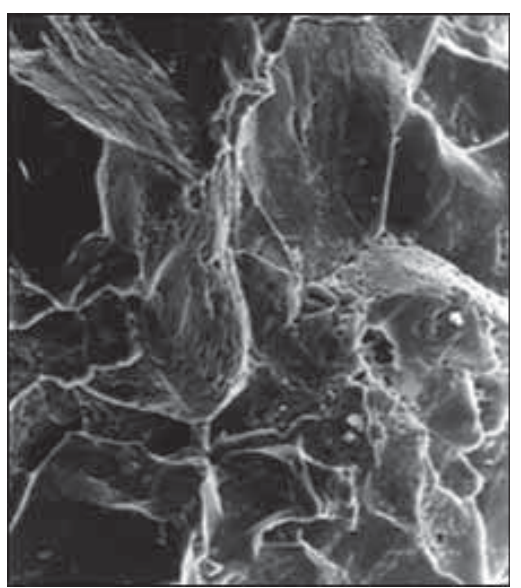

Figure 4. The angular shape of a surface of mean or high relief, with sharp-edged, shiny conchoidal walls, part of the walls matted on account of a chemical etching process and encrusting in frost cracks, no features of transport (magnification 300x, fragm. Fig. 3). 


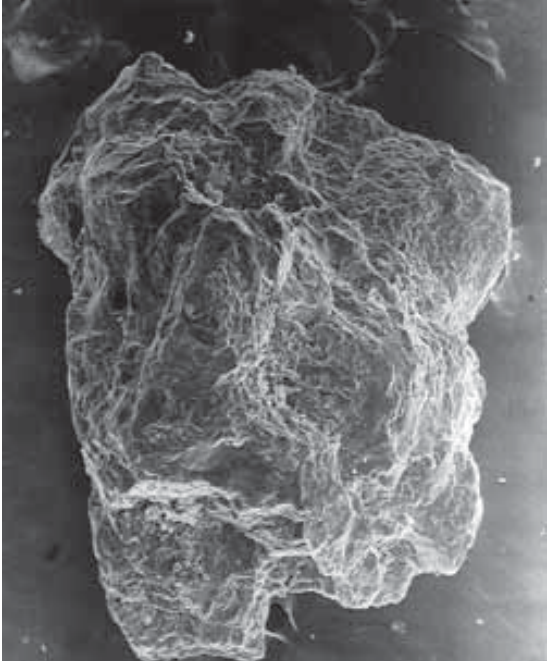

Figure 5. A spheroidal grain of feldspar with relict angular shape and high relief and average granular and blockwise mechanical breakdown,

totally matt lustre and rounded due to the domination of younger processes of chemical etching plus carapace, followed by pelitic scalling (magnification 72x, AhE horizon, depth 4-8cm,

Równia pod Śnieżką, periglacial planation).

in cool periods of the Holocene), the features generated by the dominant mechanical and chemical weathering often overlapping one another together cover up to $270 \%$ of the grain surface. They have larger dimensions than are found in the Kevo area with sand-grain surface cover reflecting features of weathering being of up to $155 \%$. However, both environments are associated with sand-grain surface features at ultramorphoscopic level that do not support the glacial or water transport - while features characteristic of aeolian transport are to be found on some quartz grains from the Kevo area (Table 1).

\section{THE MORAINE ENVIRONMENT}

A high diversity of original environments is what characterises the composition of quartz sand grains in the morainic sediments from the Central Polish Glaciation to be found in the Białowieża Primaeval Forest. In the sediments in question, there is

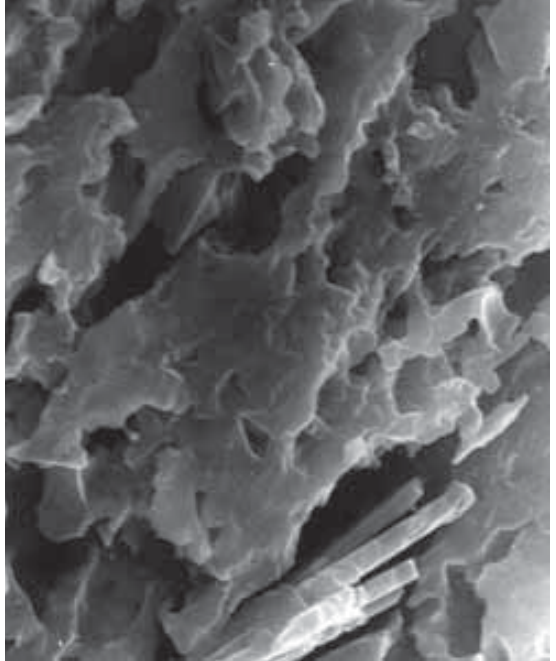

Figure 6. Spongiform chemical weathering with a network of etching micro holes and smooth shiny walls arising as a consequence of mechanical breakages (magnification 10,000x, fragm. Fig. 5).

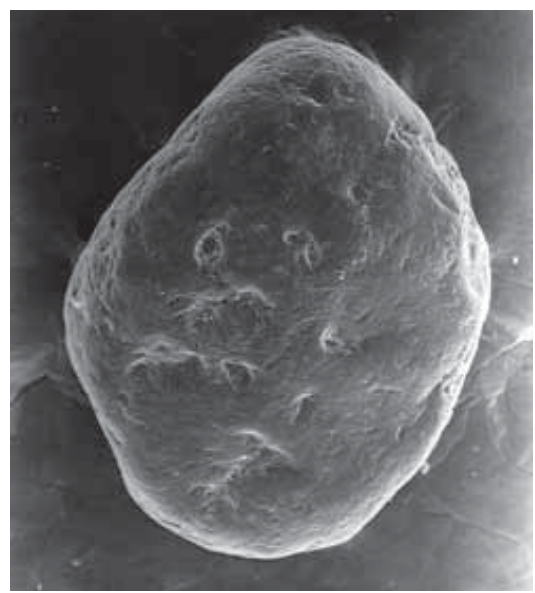

Figure 7. Spheroidal rounded quartz grain of low relief levelled out by carapaces and a surface partly polished in the course of transport by water, with rounded, convex edges relict of deep breakage and broad arcuate splitting due to glacial exaration and transport (magnification $72 x$, C horizon, depth $110-120 \mathrm{~cm}$, Białowieża, fluvioglacial sediment under congelifluctional cover of morainic material). 


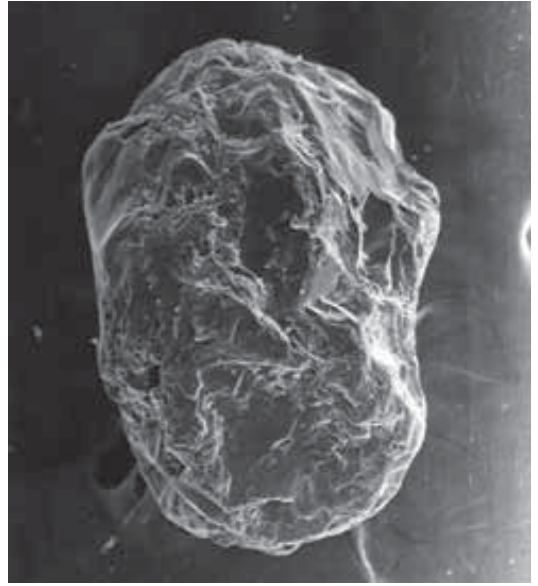

Figure 8. Spheroidal subangular and subrounded grain of quartz of mean and high relief, shiny walls of conchoidals with edges part sharp and part rounded by the breakage and swelling-induced splitting of glacial exaration (magnification $72 \mathrm{x}$, AhE horizon, depth $2-10 \mathrm{~cm}$,

Białowieża, congelifluctional sediments from terminal moraine).

a prevalence of grains of rounded shape, as well as a large share of grains that are subrounded and subangular, as well as of the mean or high surface relief arising in a glacial environment. They are characterised by relict (now broad and deep) conchoidals, often with a shiny surface, as well as linear striations of deep breakages and edges that are rounded by young glacigenic breakages (Figs. 7, 8 and 9).

On the Schaabe Bar, the grains of sand originating from far younger (allochthonous) morainic material from the North Rugia phases of the Vistula Glaciation have a rounded or subrounded and subangular shape, with high, average or low relief, with a matted or shiny surface (Table 1, Fig. 10).

Up to the moment these sands were washed out from moraine and deposited on the coastal berm of the Bar, they had not been subject to Holocene weathering processes. They had thus retained original features taken on in glacial and proglacial environments, assuming they had not been

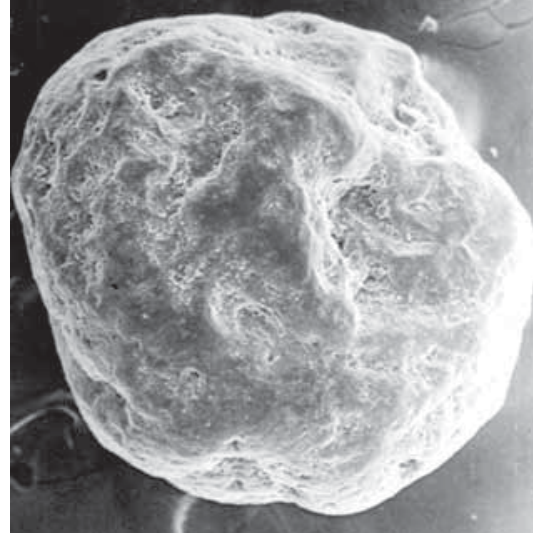

Figure 9. Spheroidal, subrounded grain of quartz with relict high, average of low glaciogenic relief of numerous arcuate splittings and pedogenetic encrustation (magnification 72x, BvBfe horizon, depth 10-20 cm, Białowieża, congelifluctional sediments at the base of a terminal moraine).

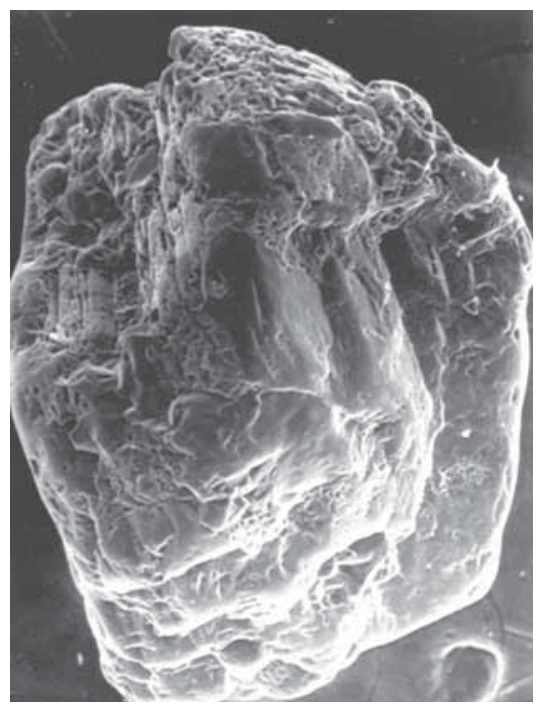

Figure 10. Subrounded grain of quartz sand with high, mean or low relief of glaciogenic blocky breakages and on the rounded edges granular and lamellar shiny breakages, covered with V-shaped splittings reflecting transport by water, young and small stepped conchoidals, depressions with ribbed and cellular caverns reflecting chemical etching (magnification 120x, Bhfe horizon, depth 60-70 cm, Schaabe Bar, brown coastal berm). 
impacted upon by pedogenetic processes or of diagnesis while in the moraine deposit.

Among the grains of glacial origin in the morainic material from the Białowieża Primaeval Forest and the Schaabe Bar, there are also grains of sand originating from the older sediments exarated from the base of the transgressing glaciers. In earlier glaciofluvial and niveo-aeolian environments, these grains took on features diagnostic of these environments, on to which were superimposed younger features of late transport by glaciers. Morainic material also sometimes includes grains released by melting of the ice sheet having already been reshaped by earlier pedogenetic processes (Kowalkowski and Kocon, 1991). There is thus marked differentiation to the quantitative-qualitative differences in origin pertaining to the grains of quartz sand in morainic material. This is true not only of formerly glaciated areas, but also within the local ranges of sediments (Cailleux, 1942).

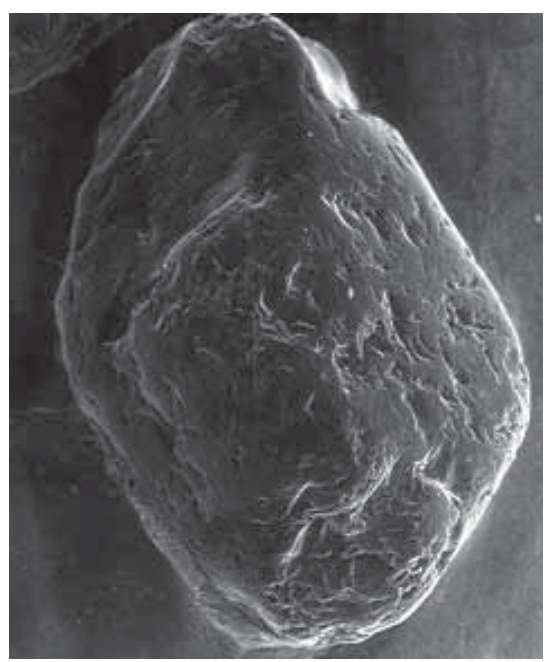

Figure 11. Spheroidal subrounded and rounded grain of quartz of prevailingly low and partially mean relief, polished by beach tooling, with numerous relicts of lamellar and granular breakages, as well as conchoidals due to glacial transport (magnification 78x, Bfe horizon, depth

$70-78 \mathrm{~cm}$, Hel Peninsula, coastal berm).

\section{THE BEACH ENVIRONMENT}

Grains of quartz sand with beach "processing" occur in different sediments of the Białowieża Forest study point. They are present sporadically in morainic sediments, but mainly in the studied glaciofluvial sands, in which the proportion accounted for by them amounts to $11 \%$ on average. On the $\mathrm{Hel}$ Peninsula, their content in the fossil beach sediments studied beneath the sea bank is high, amounting to $75.2 \%$, as compared with $21.1 \%$ in the marine sediments of the brown coastal berm on the Schaabe Bar (Table 1).

The diagnostic features of such grains of sand include prevalent (77.2-82.5\%) cover of the surface, a rounded and flattened shape and low relief on $76.5-85.5 \%$ of the grain surface cover on average, and a usually shiny surface when in marine sediments (Figs. 11, 12 and 13), in connection with the relatively limited presence of features relating to chemical weathering - present over just 20-28\% of grain surfaces on average. An exception are the old Pleistocene beach grains found in

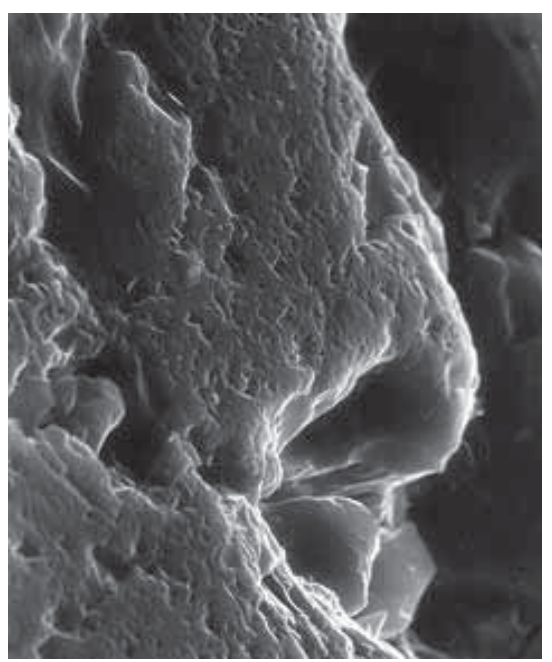

Figure 12. Relict breakages with sharp-edged shiny walls and conchoidals, upper edges rounded, on a levelled-off surface there are many partially-overlapping $\mathrm{V}$-shaped and unidirectional arcuate splittings reflecting mechanical tooling on the beach and by the sea

(magnification 3000x, fragm. Fig. 11). 


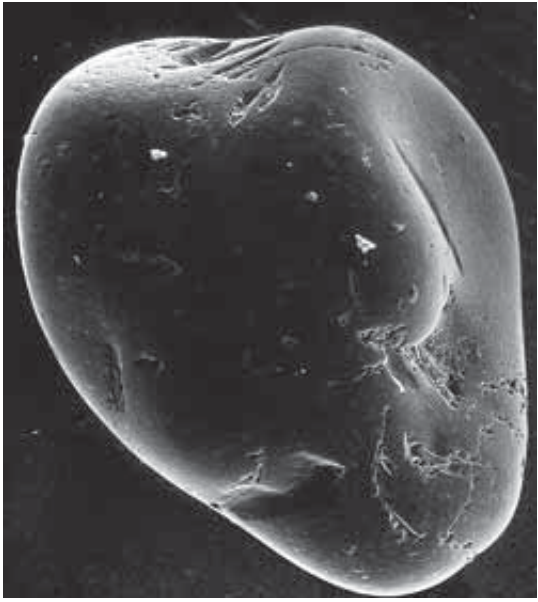

Figure 13. Spheroidal rounded and flattened grain of quartz of low relief, very much smoothed and polished with numerous relicts of mean and high relief of large arcuate conchoidal breakages and splittings (magnification 86x, D horizon, depth 180-190cm, beach below the coastal berm, Hel Peninsula).

the Białowieża Primaeval Forest (on whose surfaces there are features of chemical processes), these accounting for $78.5 \%$ of the total on average, and possibly being associated with pedogenetic processes that have been prolonged (since the Late Pleistocene at least) and have taken place in an acid or acidifying Holocene soil environment.

Also characteristic for the aforementioned grains is the relatively abundant and diversified presence of the features of mechanical processing, on average over between 96.3 and $133.5 \%$ of the surface of the quartz-sand grains studied. These are mainly continuous surfaces covered in the small and shallow V-shaped and semi-rounded, sharp-edged depressions left by chipping, and the linear or pseudodendritic breakages induced by shore and beach transport, readily recognisable on micrographs at $8000 x$ magnification. A characteristic feature concerns their unidirectional configurations, particularly on flattened or convex parts of grains (Figs. 11, 12 and 13). Only much more rarely are these deeply-incised arcuate, dendritic and polygonal relict fractures

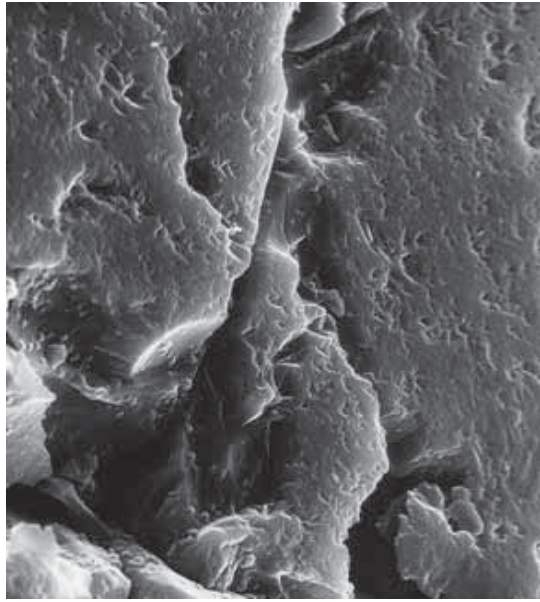

Figure 14. Relict series of long, arcuate, sharp-edged bottoms of conchoidal breakages, flat and levelled rounded surface with numerous aggregations of V-shaped and arcuate (often overlapping) splittings of mechanical beach tooling situated unidirectionally on the surface of the quartz grain (magnification 3000x, fragm. Fig. 12).

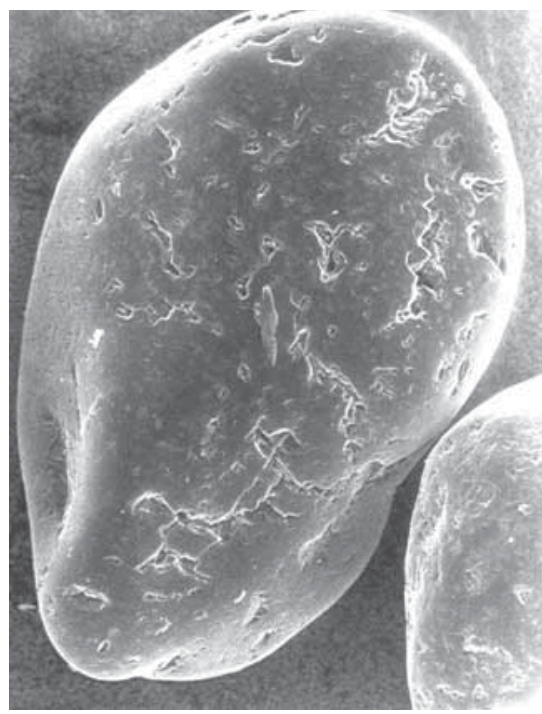

Figure 15. Rounded grain of quartz sand with low relief, shiny surface, showing Beach abrasion, numerous relict rounded conchoidals, as well as dendrite-like glaciogenic breakages (magnification 110x, D horizon, depth $180-190 \mathrm{~cm}, \mathrm{Hel}$ Peninsula, Jurata, beach below the coastal berm 
with smooth and shiny walls externally and bottoms having features of conchoidal, fractured multidirectionally with sharp and even facets that are indicative of an earlier glacial environment (Figs. 13, 14 and 15).

Many grains also have linear arcuate scratches, with rounded edges, cutting across both elevated and depressed parts of the rounded surface of these grains. These are the remains of large conchoidals arising in glacial and periglacial environments as a result of pressure disintegration, as well as hydrothermic chipping of micro-cracks, later abraded mechanically from the grain surface in an aquatic beach environment (Figs. 14 and 15).

\section{THE ENVIRONMENT OF COASTAL BERMS}

The coastal berms studied on the Hel Peninsula (Jurata area) came into existence over a period of the last 3000 years, thanks to the accumulation of debris transported by sea currents oriented eastward in the direction of the Gulf of Gdańsk (Kostrzewski, 1999). The material is usually of varying geological genesis, though it mainly comprises glacial sediments originating from beach abrasion and sea cliffs (in the case of Jurata present some $27-35 \mathrm{~km}$ away). In connection with this, ultramorphoscopic features on the surfaces of grains of sand from these sediments are similar to those in material of glacial origin (Degórski et al., 2012). Grains of quartz mainly have rounded or subrounded shapes, these features together accounting for around $75 \%$ of the surface. They are sometimes subangular and they have mainly low or mean relief equal to $96 \%$ of the surface, with grains occasionally presenting features of high relief (Table 1). Features of mechanical weathering account for 104\% of the grain surface on average, those of chemical weathering for $23.7 \%$, giving a total cover of $127.7 \%$ of grain surfaces. They are nevertheless far weaker than in the studied morainic material of the Białowieża Forest and the Schaabe Bar (Table 1). This is the result of mechanical abrasion during transport in shallow coastal and near-shore waters.

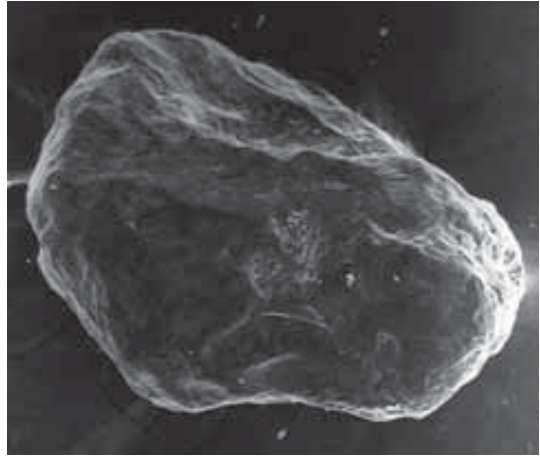

Figure 16. Spheroidal subangular and subrounded grain of quartz with relict high and mean relief reflecting glacial transport, as well as rounded edges and convexities with the moderate and high relief characterising marine transport, highly fractured edges with wall surfaces of shiny or dull lustre (magnification $94 \mathrm{x}$, horizon $\mathrm{C}$, depth $120-130 \mathrm{~cm}$, Hel Peninsula, coastal berm).

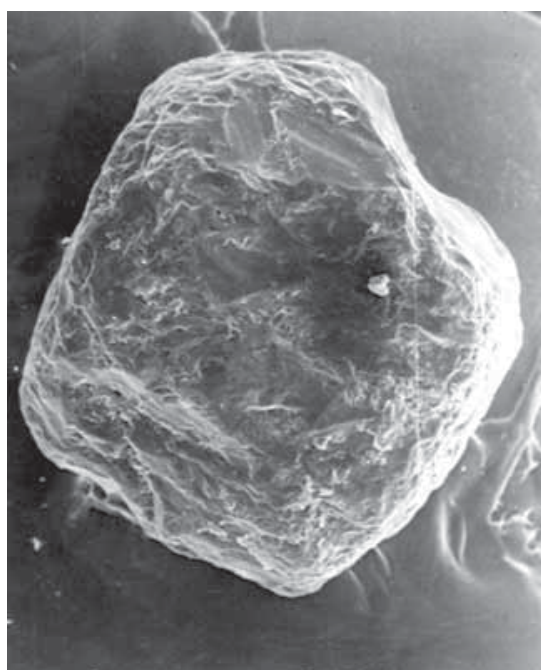

Figure 17. Rounded grain of quartz sand with mean or low relief, matted, large relict pellicular and granular encrustings with cryogenic crevassed chippings and shallow caverns of selective scalling, on the grain edges young smaller or larger lamellar breakages with shiny surfaces (magnification 100x, C horizon, depth 120-130 cm, Hel Peninsula, Jurata, coastal berm) 
The surface of grains of subangular and angular shape with mean or high relief have numerous forms of processing due to mechanical and chemical weathering, and are relicts of a glacial and periglacial environment. Superimposed on these are features of marine transport, as well as subsequent pedogenetic chemical breakdown ongoing in both the Late Pleistocene and Holocene environments (Figs. 16 and 17). On coastal berms they are also present as an admixture of numerous grains showing signs of beach and sea water tooling (Figs. 11 and 12).

\section{THE DUNE ENVIRONMENT}

The presence of grains with features indicative of aeolian reworking of their surfaces was reported in small quantities (accounting for about $8 \%$ of the total) in the material originating from the upper eluvial (E2) horizon of podsolic soils in the brown and yellow coastal berms on the Hel Peninsula. The small share of quartz grains with features of aeolian genesis in the white-coloured E2 horizon (as a young soil cover on the surface of a podsolic soil) is a reflection of short-distance aeolian and fluvial transport of already-blanched sand lacking mechanical abrasion (Degórski et al., 2012). Sporadically (at a frequency of around $1 \%$ ), grains of quartz with features of aeolian processing are also present in the Kevo area, in the upper podsolic soil layers Ahe and E (Table 1).

The characteristic features of aeolian grains are rounded surfaces in $80-90 \%$ of cases on average, as well as partially being to some extent subrounded, without angular features and with associated low relief on $80-90 \%$ of the surface, with no features of high relief.

The studied grains displaying features of aeolian genesis are characterised to a high degree by matted surfaces, the proportion reaching $80-85 \%$ on average (Figs. 18, 19 and 20). Features of mechanical weathering, mainly aeolian mechanical abrasion in the form of small, multi-directional fracturing and $\mathrm{U}$ - or $\mathrm{V}$-shaped chipping are visible on SEM micrographs when the magnification exceeds 300x (Fig. 20).

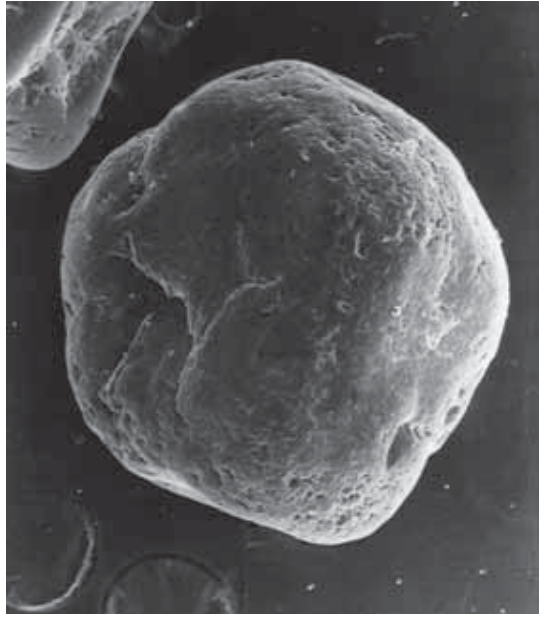

Figure 18. Spheroidal, rounded and matted grain of quartz with low and partially high relict relief of large conchoidals with rounded edges, convex edges covered with granular breakages and splittings of mechanical aeolian tooling (magnification 72x, Ees horizon, depth $15-20 \mathrm{~cm}$, uppermost part of the coastal berm, Hel Peninsula).

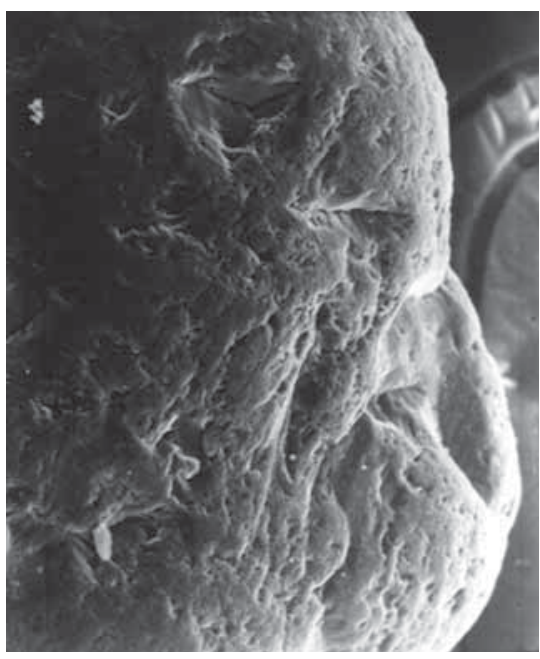

Figure 19. Edge of rounded, matted grain of quartz with old and large conchoidals and convex walls with strong aeolian abrasion (magnification 300x, Bhfe horizon, depth 31-36cm, aeolian cover on the coastal berm, Hel Peninsula). 


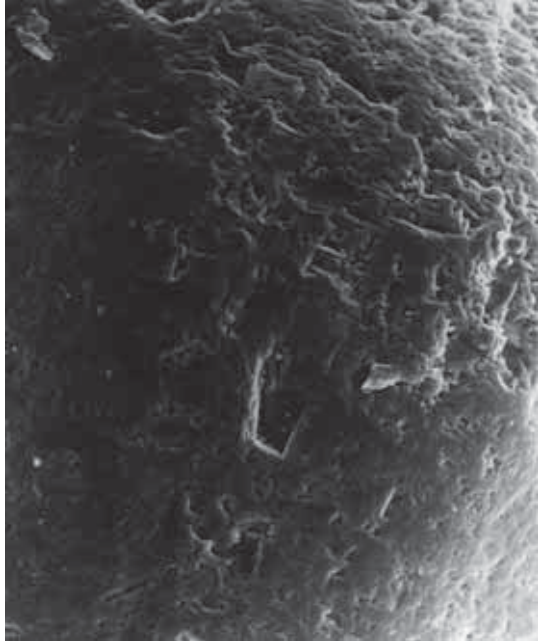

Figure 20. Edge of rounded grain of quartz of matted lustre with U- and V-shaped unidirectional breakages and splittings reflecting mechanical aeolian abrasion (magnification 300x, fragment Fig. 18).

The rounded surfaces of aeolian grains often feature extensive linear or arcuate relict features of block and tabular fracturing with ribs of conchoidal fracturing from earlier glacial and periglacial environments taking shape. These are often complexes of matt-surfaced relicts of successive earlier environments in which they present, for example being indicators of old transformations of the surfaces of grains whose residual features are preserved on surfaces modified by aeolian abrasion or through younger deposition of silicate encrustation. The youngest features coinciding with aeolian abrasion may be taken to include small oval ones often concentrating in grain-surface depressions, small caverns reflecting chemical weathering to various depths and with various shapes. On the studied grains of sand they cover $10-20 \%$ of the surface area (Table 1). Features of aeolian abrasion seen particularly well on large surfaces of the edges of sand grains (Figs. 17 and 18) may also be found on the crust arising in environments that are periodically wetter (Fig. 20).

\section{COMPLEXES OF MECHANICAL AND CHEMICAL PROCESSES ON THE SURFACES OF GRAINS OF SAND IN SOIL PROFILE CONFIGURATIONS}

Detailed publications from the second half of the $20^{\text {th }}$ century and first years in the $21^{\text {st }}$ - like those by L. de Ribault $(1975,1977)$, W. C. Mahaney (1995), P. Helland and M. Holmes (1997), P. Helland et al. (1997), G. Schwamborn et al. (2006), B. Woronko and M. Ostrowska (2009) - all point to the possibility of clear links between ultramorphoscopy of the surfaces of sand grains and their morpholithological genesis, and hence the genesis of different genetic horizons in the soil profile, according to Z. Brogowski and J. Kocoń (1984), A. Kowalkowski (1984, 1988a, 1988b), and M. Degórski et al. (2012). Thus the application of research into the morphology of the surfaces of these grains and their shapes with the aid of SEM techniques thus creates real premises upon which knowledge can be extended regarding complicated polychronic and polygenetic soil profiles in different geographical regions - notwithstanding the existence of many difficulties and reservations as regards methodology.

According to H.A. Anderson et al. (1982), V.C. Farmer (1984) and A. Scheidegger et al. (1992), the covering of grains of quartz sand, dusts and silts with a cutan of sesquioxides is probably the initial phase of a process underpinning the appearance of a podsolic soil profile. Bearing in mind the theory regarding the overlaying of features of the podsolisation process upon the profiles of rusty soils, it would be necessary to accept a paradigm holding that the $\mathrm{B}$ horizons of such soils should be characterised by the presence of two types of sesquioxide cutans - an older, continuous and very persistent one associated with dominant weathering processes, and one overlain upon it involving what are generally less-durable and often discontinuous arising through the podsolisation process itself. In young podsolic soils, there are only sesquioxides with humus deposited during the podsolisation process. 
Thus remaining to be resolved is the matter of the separate ultramorphoscopic interpretation of the features arising out of three sets of processes on the surfaces of grains of sand, dust and silt in the B horizons of rusty podsolic soils, which is to say the processes of weathering of solid rock and of the transport of weathered debris, as well as the pedogenetic features of the rusting and podsolisation processes. The adopted method of cleaning the surface of sand grains in $10 \%$ $\mathrm{HCl}$ results in the removal of readily-soluble carapaces and encrustings that are deposited on grain surfaces in the course of the podsolisation process, and thus the uncovering of the underlying, older-generation mechanical and chemical features of lithogenetic and pedogenetic processes (Degórski et al., 2012), as well as the pre-weathering surfaces (Mahaney and Kalm, 1995; Mahaney, 1995; Rose and Hart, 2007).

In the work presented here, quartz sand grains cleaned using $10 \% \mathrm{HCl}$ were made subject to the classification of features of processes of the mechanical and chemical working of sand grains that encompassed the ultramorphoscopic categories and sub-categories which compiled.

When it comes to the long-term impact on the surfaces of quartz sand grains, generally applicable regularities owing to different, temporally variable configurations of external factors involve characteristic sets of features arising out of physical processes impinging in particular upon edges and surface convexities, as well as chemical and biochemical processes mainly operating in surface depressions. These locations are often modified by processes dependent on the environment conditions and on the ages of grains, as well as on crystallographic structure. Markedly advanced processes of the disintegration of grain surfaces (in particular in glacial and periglacial environments where glaciophysical, as well as cryophysical and cryochemical, processes prevail) lead to angular, near-spherical shapes being assumed, with high or mean high relief. The end result is in turn the physical disintegration of the quartz grain into sharp-edged chips of diameters in the range 0.6-0.003 $\mathrm{mm}$ (Kowalkowski, 1984, 1988b; Kowalkowski and Brogowski, 1983, Kowalkowski and Kocoń, 1991; Rose and Hart, 2007; Schwamborn et al., 2006).

\section{TEXTURAL FEATURES OF THE MECHANICAL PROCESSING OF GRAINS}

Distinguishing ultramorphoscopic diagnostic features connected with the complex of mechanical processes involved in different forms of grain-surface abrasion and disintegration in the soils of the geographical regions studied include splitting, chipping, scalling, breakage, conchoidal formation. These are morphological forms present on differing scales, with shiny, sharp-edged walls and conchoidal fracturing. The morphological forms of splitting (in the form of large V-and U-shaped breakages of aeolian origin distributed unevenly and multidirectionally on the surface of grains, as well as small V-shaped and U-shaped and arcuate directional ones originating in the course of transport by water) are present on quartz grains from the profile of podsolic soil horizons at Jurata, on the Hel Peninsula and the Schaabe Bar. Shiny, convex and rounded grains indicative of beach processing are $58-100 \%$ covered by surfaces showing features of having been abraded by water (Figs. 13, 14 and 15), while subangular and subrounded grains transported in sea water are associated with 17 to $86 \%$ of surfaces (Figs. 16 and 17). Features of aeolian abrasion appear sporadically on these grains. In the weathering soil horizons at Równia pod Snieżką, features associated with processing by water or the wind are not present at all, while at Kevo they are sometimes present on single grains blown on to slope soil-cover. In the studied Białowieża rusty podsolic soils there are grains of beach or aeolian abrasion mixed in with morainic material in all horizons.

Prevalent in the soils at Równia pod Śnieżką and Kevo are features of chipping characterised by a net of micro-cracks in tetro- to hexagonal configurations of differ- 


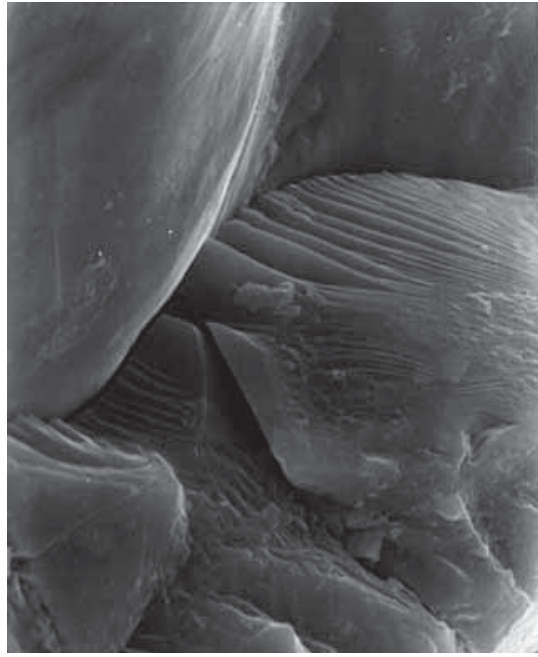

Figure 21. Walls of multidirectional imbricate conchoidals with crevices due to large-block frost chopping by the edge of the angular grain that has been subject to powerful mechanical weathering (magnification 3000x, BvtBfe horizon, depth 10-14 cm, Kevo).

ent cross-section, with sharp-edged walls, sometimes rounded by crusts that have been laid down or by processes of chemical decay. These are features of cryogenic blocky, granular or lamellar chipping of different dimensions (Figs. 21 and 22), arising mainly under the influence of 24-hour temperature dynamics, freeze-thaw frost processes, and chipping pressures resulting from the impact of ions with diameters smaller than that of molecules of water present in micro-crevices of the grains in hydrated environments. In these soils at Równia pod Śnieżką, such features occur in all horizons, accounting for between 39 and $96 \%$ of grain surfaces. At Kevo they occupy between 7 and $67 \%$ of the grain surface, being shaped most intensively in the Ehl and BvtBfe horizons. The studied soils at Białowieża and Jurata and on the Schaabe Bar are characterised by a sporadic and variable $(0-18 \%)$ cover of grain surface by these features. It is usual for these to be relict forms preserved on abraded roundings of sand-grain surfaces.

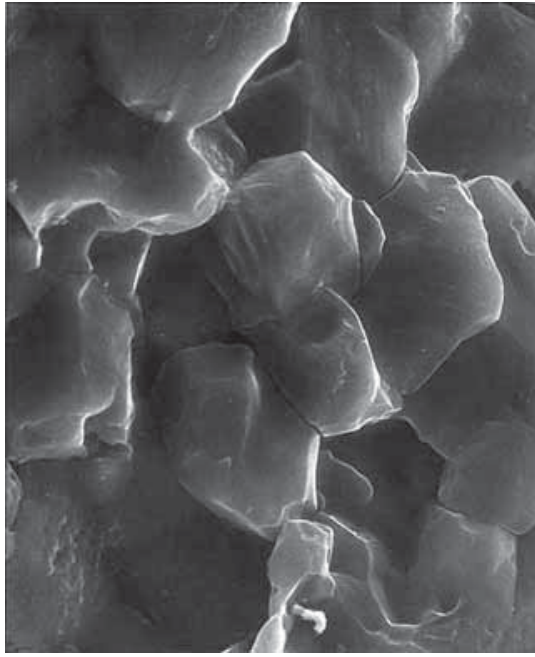

Figure 22. Network of crevices with granular frost chopping, superficial walls of aggregate covered with cutans of carapaces, grain of morainic origin (magnification 3000x, Bfe horizon, depth 70-78cm, Białowieża Primaeval Forest).

Features of grain-surface scalling processes arise under the influence of numerous temperature fluctuations of short duration above or below zero, two-direction ionic expansion into micro-cracks in conditions of the abundant presence of water on grain surfaces and saline disintegration, mainly in proglacial and periglacial environments. These forms of scalling - known as cryohydrothermic (Kowalkowski, 1988b) - stand out for being superficial and selective. Depending on the relief of the grain surfaces they are usually covered with layers of coarse and fine-grained, lamellar and scaly detritus, characterised by the presence of sharp-edged facets (Fig. 23). Proportionally the greatest surface areas (of between 18 and $95 \%$ ) are accounted for on grains of sand from all horizons of the rusty podsolic soils at the Białowieża study area, with a prevalence of selective scalling. All the soil horizons at Równia pod Śnieżką have grains with selective $13-65 \%$ scallings on the surface in lamellar and scaled forms. In contrast, at Kevo it affects small (5-10\%) proportions of the surfaces of grains from the Bvt and CBvt horizons. 


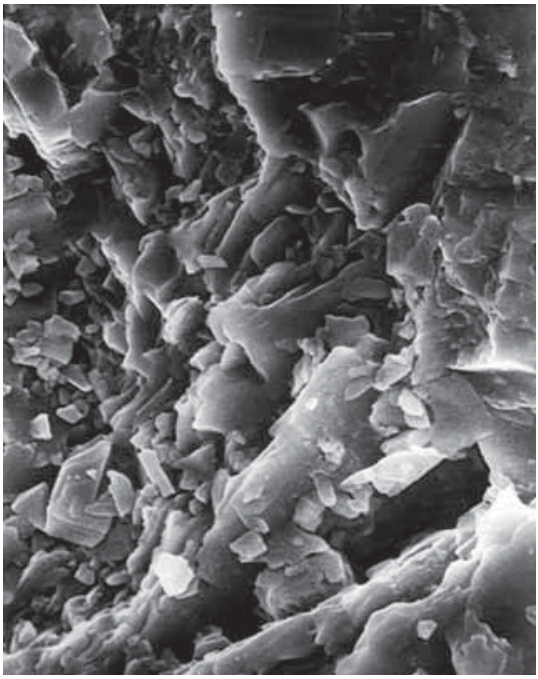

Figure 23. Lamellar/scaled sharp-edged wall in the angular cavern on a scalling weathered grain (magnification 2000x, CBvt horizon, depth 25-35 cm, Kevo).

In the podsolic soils generated from coastal berm sediments at Jurata there are features of the processes of granular and lamellar scalling over between 20 and $30 \%$ of the surfaces of grains of morainic origin. In contrast, on beach grains it is usual for these to be absent or else a trace presence only. In the soils from marine alluvia on the Schaabe Bar there is a lack of features of exfoliation, only traces being reported in the different horizons.

The edges of quartz sand grains usually have breakages differentiated into the large or small blocky, large or small granular or lamellar types, arising mainly through high lateral pressure at the point where edges make contact with adjacent grains in a freezing environment, in processes of exaration and glacial transport, as well as the thermal decay of grains. These features are frequent in the profiles of horizons from all of the soils studied. They are reflected in the generations of old or young conchoidals large or small, stepped, imbricated and arcuate (Fig. 24). Distinctly limited areas of breacages, mainly of the lamellar kind with fresh sharp-edged walls, respectively occupy rusty

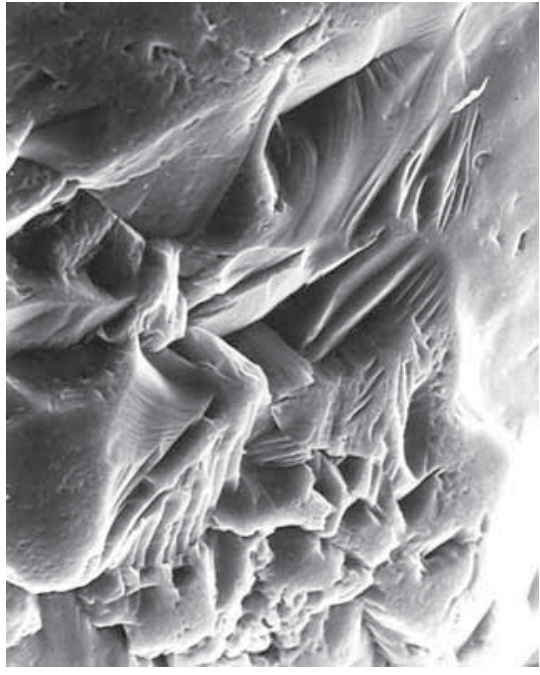

Figure 24. Multidirectional conchoidals stepped and imbricated fracturing of a lamellar, granular or scaled shape, on the rounded edge of a grain of morainic origin in marine alluvia

(magnification 1000x, Bfe horizon, depth $60-70 \mathrm{~cm}$, Schaabe Bar).

podsolic soil horizons to the tune of $10-$ $35.5 \%$ and $0-54 \%$, suitable at Równia pod Śnieżką and at Kevo. In all horizons of the rusty podsolic soil studied at Białowieża, the surfaces of the more or less rounded grains of sand show features of older granular breakages, on rounded edges of subangular grains irrespective of their origin, over between 20 and $95 \%$ of their surface. Relatively lesser percentage (in the range 15-35\%) are taken by the different forms of breakage on the surfaces of the sand-grains from all horizons of the podsolic soil studied at Jurata. More distinct and fresh, the mainly shiny and sharp-edged breakages over a greater proportion $(10-83 \%)$ of the surface area, these are features in all the horizons of the young gley-podsol on the Schaabe Bar.

Morphoscopic features of the cryogenic $\mathrm{V}$-shaped and arcuate incision and conchoidals of quartz grains, as associated with glacial and periglacial environments and the zone of permafrost, are present only sporadically in the soils studied. This is also true of the cryogenic blocky-chipping of these 
grains and the periodic crevice, cellular and reticulate exsiccations in encrustings and carapaces of various types. The presence of these features was noted in superficial horizons of the soils at Równia pod Śnieżką, Kevo and Bialowieża, as well as on gley-podsol on the Schaabe Bar.

\section{TEXTURAL FEATURES OF THE CHEMICAL PROCESSES OF THE ABRASION OF SAND GRAINS}

Among the features typical of chemical processes, there are two categories that characterise the deposition on the surfaces of quartz grains of silicate encrustings and carapaces as well as one typical processes of chemical etching. The encrustings usually cover small areas of grain in weakly-soluble crystalline or mainly amorphous silicates of local origin, or else are washed in and deposited in granular, euhedral, sheeted, cellular, bridged or spongy form, arising in the various environmental conditions typical for them (Fig. 25, 26). The greatest area overall is taken by the encrustings on the sand grains from the soil studied at Białowieża. In the studied horizons of rusty podsolic soil, they occupy between 6.6 and $90 \%$ of the surface, with a prevalence of sheeted and granular forms. On the smoothed surfaces of beach grains, these cover proportionally the great $(24-52 \%)$ surface area, the greatest $73-90 \%$ on morainic grains. Sporadically, there are bridged and spongy forms indicating a sustained period of higher soil humidity. In the weathered rusty podsolic soils at Równia pod Śnieżką, encrustings usually cover a smaller (7-43\%) area of grains. They are most limited in the OAhe and $\mathrm{E}$ horizons, and greatest in the BvtBhfe and $\mathrm{CBv}$ horizons, mainly in granular form. A much lower (4-20\%) percentage cover of grains by encrustings is present in the horizons of the young rusty podsolic soils at Kevo. These are mainly sheeted and spongy forms, also indicative of sustained high soil humidity. At Jurata, encrustings occupies limited (1-22\%) surface area,

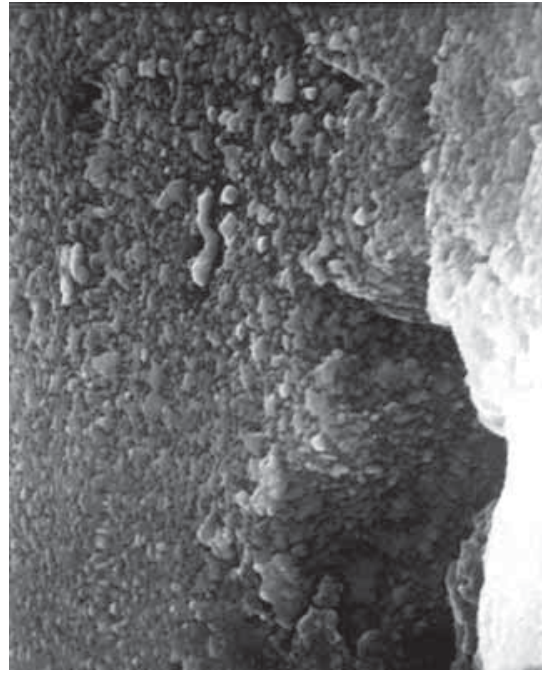

Figure 25. Granular encrusting with a silicate flower on a beach grain surfaces with relict breakage, in sediments of marine alluvia (magnification 7800x, E2 horizon, depth $12-20 \mathrm{~cm}$, Schaabe Bar).

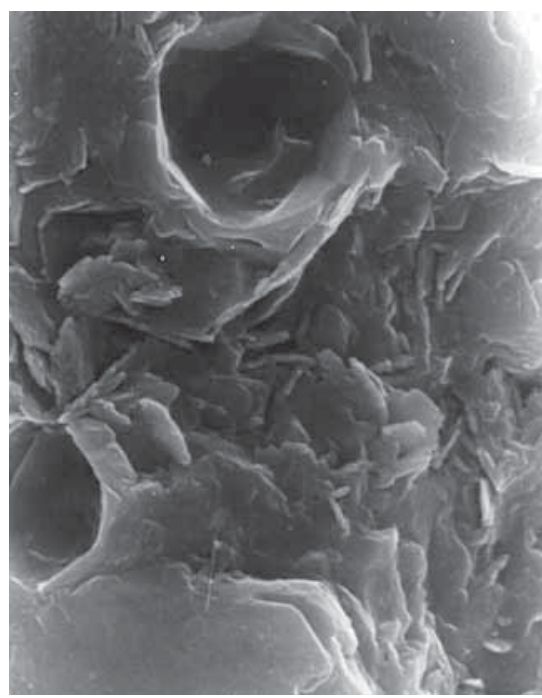

Figure 26. Sheeted and bridged encrusting with pellicular formless carapaces by the edge of a morainic grain rounded by abrasion due to transport by water in marine alluvia (magnification 3000x, Cfegg horizon, depth $110-115 \mathrm{~cm}$, Schaabe Bar). 
mainly with granular forms, sporadically also sheeted, cellular or spongy forms. In contrast, on the Schaabe Bar, these forms only occur in the E2 and E1Bhfe and Cfegg horizons, on very limited (3-15\%) percentage areas of morainic grain surface. They occur sporadically in deeper horizons.

Carapaces are more extensive, cohesive continuous forms enclosing grains, also beach grains on $4-123 \%$ of the grain surfaces. In the studied soils, they create forms that are lamellar, granular, bridged, sheeted, scaled, spongy, fluidal, pellicular and amorphous (Fig. 26). They were not reported from the Ahe and $\mathrm{E}$ horizons of the soils at Białowieża and Jurata and on the Schaabe Bar, where there are none at all throughout the soil profile. In the BvBhfe and $\mathrm{Bv}$ horizons of Białowieża's rusty podsolic soils they are on large percentage areas from 30 to $90 \%$ of the grain surface of morainic sand, unlike in the D horizon of a fluvioglacial substratum where they ac-

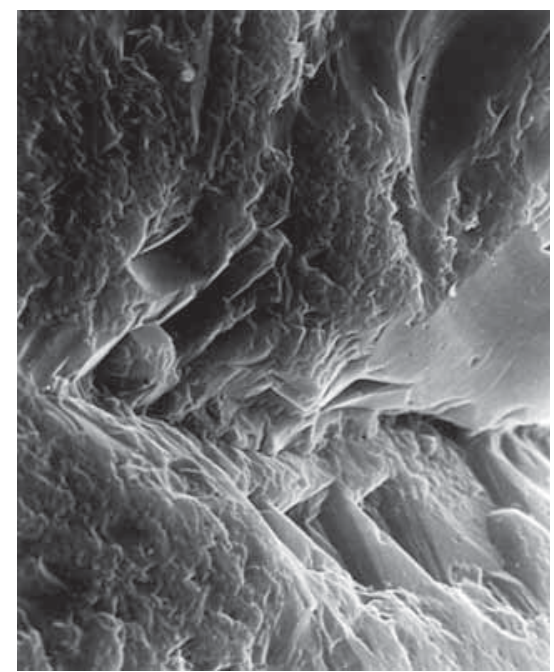

Figure 27. V-shaped etching of the side wall of a glacial breakage, partially with granular encrusting. On the convex edges there are numerous V-shaped splittings and granular treakages. This subrounded grain deriving from transport by water in the coastal berm (magnification 3000x, Bhfe horizon, depth 32-36 cm, Hel Peninsula). count for just $6-10 \%$ of the grain surface. These are mainly sheeted forms. Characteristically increasing down the profile from $0-123 \%$ of the surface, pellicular and granular carapaces with a share of sheeted and lamellar ones are also present in the soil horizons at Równia pod Śnieżką. Their distribution attests to the intensive translocation of silicate gels down the profile, as well as to their deposition in the cemented lower part of the profile. In the young rusty podsolic soil at Kevo, in contrast, sheeted carapace only is present on very limited (9-1.4\%) areas of the grain surface in the upper Ehl, BvtBhfe and Bvt horizons. B horizons and the beach substratum D in podsolic soil at Jurata manifest carapaces over 1.5 to $27 \%$ of the sand-grain surface, with pellicular, occasionally scheeted, lamellar or granular, forms assumed.

The features of chemical etchings in the studied soils from different geographical areas are very diverse from the point of view of the area of surface occupied, as well as form assumed (Figs. 27 and 28). Forms distinguished are V-shaped, ribbed, scaled, linear, lamellar, cellular, spongy,

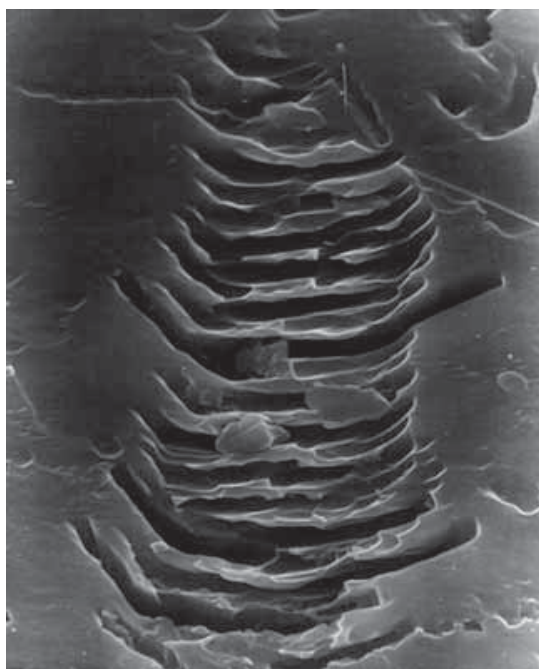

Figure 28. Ribbed etching on a smooth conchoidal with sharp edges on the angular grain of mechanical weathering (magnification 4000x,

Bvt horizon, depth 14-25 cm, Kevo). 
dendritic and arched. The smallest areas of grains are taken by features of chemical etching on sand grains in the rusty podsolic soil at Białowieża. In the Ahe horizon they are between 15 and $31 \%$ in cellular form, sporadically in ribbed or dendritic form. In lower horizons $\mathrm{BvBfe}, \mathrm{Bv}$, and $\mathrm{CBv}$ they are not present, though they may be covered in carapace that can only be dissolved way with difficulty. Relatively high (51.4$176 \%$ ) percentage surfaces are occupied by features of etching of grains of the Ofh and $\mathrm{E}$ horizons in the rusty podsolic soils at Równia pod Śnieżką, with a prevalence of V-shaped, ribbed, lamellar, spongy and dendritic forms. In lower-lying horizons these features account for $4-43 \%$ of grain surfaces. Through the whole rusty podsolic soil profile at Kevo also, features of chemical etching account for $68-17 \%$ of surfaces, the percentage declining with depth. Podsolic soils that developed on the coastal berm from marine sediments at Jurata vary greatly (between 0 and $50 \%$ ) in terms of chemical etching of surfaces. The greatest are found in Bfe horizons. It is mainly $\mathrm{V}$-shaped forms that are involved, sporadically also scaled, lamellar, cellular and dendritic ones. The surfaces varying most as regards etching (in the range 10-100\%) characterise the quartz sands of the studied gley-podsol soils on the Schaabe Bar. There is a prevalence here of V-shaped, cellular, spongy and dendritic forms, with only limited shares of the ribbed, linear and lamellar forms indicative of intensive pedogenetic processes.

\section{CONCLUSIONS}

The results presented here from analysis of scanning electron microscope (SEM) micrographs of the surfaces of quartz sand grains of diameters $0.6-0.8 \mathrm{~mm}$ selected from soil profiles in geographical areas of different ages and stratigraphies, and as prepared by washing in a $10 \%$ solution of $\mathrm{HCl}$, allow for the following general conclusions to be formulated:
1. Through the period from the Pleistocene to the present, weathered debris and sediments have arisen in different geographical environments with spatially-variable and temporally non-constant and/or alternating conditions as regards mechanical, chemical and biochemical processing. At different times and places they have provided substrata for the development of successive generations of soils with their diagnostic genetic horizons. Thus, the component mineral grains contained within soils have on their surfaces measurable features and properties reflecting the whole cycle of lithogenetic and pedogenetic transformation.

2. Mineral grains with chains or chronosequences of features and properties modifying their size, shape and lustre are polygenc, polyenvironmental components of soil and are thus potential sources of information as regards palaeogeographical history.

3. Diagnosis in respect of differently-aged sets of categories of the textural, lithogenetic and pedogenic features accumulated on the surfaces of mineral grains (and taking account of successive phases of their emergence and further (re)modelling) may reveal total surface areas occupied by the different types of feature that exceed $100 \%$.

4. The method of treat sand grains in a $10 \%$ solution of $\mathrm{HCl}$ (as recommended in the study of weathering, transport and sedimentation environments) does not guarantee adequate recognition and interpretation from SEM micrographs of the generation of textural, mechanical and biochemical features arising out of the action of a complex of litho- and pedogenetic processes in the different geographic environment conditions (including pre-weathering features). The devising of a complex method allowing for the exposure of the successively earlier generations of features and textural properties present on the surfaces of sand grains is thus indicated. 


\section{REFERENCES}

Anderson, H.A., Berrow, M.L., Former, V.C., Hepburn, A., Russel, J.D., Walker, A.D. (1982), A reassessment of the podzol formation process, Journal of Soil Science, 33: 125-136.

Bednarek, R. (1988), Próba zastosowania mikroskopii elektronowej $i$ mikroanalizy rentgenowskiej $w$ badaniach genezy poziomów rdzawych $w$ niektórych glebach piaskowych [Use of electron microscopy and X-ray microanalysis in the study of rusty horizons on some sandy soils], in Mycielska-Dowgiałł, E. (ed.), Geneza osadów i gleb w świetle badań $w$ mikroskopie elektronowym [Genesis of deposits and soils in light of the electron microscope research], Wydawnictwa Uniwersytetu Warszawskiego, Warszawa, 115-124.

Bednarek, R. (1991), Wiek, geneza i stanowisko systematyczne gleb rdzawych $w$ świetle badań paleopedologicznych $w$ okolicach Osia (Bory Tucholskie) [Age, genesis and systematic position of rusty soils in line to the palepedological study in Osie region (Bory Tucholskie)], Rozprawy UMK, Toruń.

Brogowski, Z., Kocoń, J. (1984), Morfologia powierzchni ziarn piasku w różnych poziomach genetycznych gleby brunatnej wytworzonej z gliny ciężkiej [The morphology of the grain sand surface in different genetic horizons of the brown soil formed from the heavy clay], Roczniki Gleboznawcze, 35,1: 115-124.

Bull, P. A. (1984), Scanning electron microscope studies of sediments, in Green, H.S. (ed.), Pontnewydd Cave: A lower palaeolithic hominid site in Wales, The first report, National Museum of Wales Press, 77-87.

Bull, P.A. (1986), Procedures in environmental reconstruction by SEM analysis, in Sieveking, G. i Hart, M.B. (eds.), The Scientific Study of Flint and Cherts, Cambridge University Press, 221-226.

Cailleux, A. (1942), Les actions eoliennes periglaciaires en Europe, Mémoires de la Société Géologique de France, Paris, 46.

Degórski, M. (2004), Geografia gleb jako dyscyplina fizycznogeograficzna [Soil geography as a discipline of physical geography], Przeglad Geograficzny, 76, 3: 271-288.

Degórski M., Kowalkowski, A., Kozłowska, A. (2012) (in press), Geograficzne trendy i dys- kontynuacje procesów rozwoju gleb bielicoziemnych, [Geographical trends and discontinuation of the podzolic soil developing processes], Monografie, Instytut Geografii i Przestrzennego Zagospodarowania (IGiPZ), PAN, Warszawa, 344 pp.

Farmer, V.C. (1984), Distribution of allophane and organic mater in podzol B horizons: Reply to Buurman and Van Reeuwijk, Journal of Soil Science, 35: 453-458.

Helland, P.E., Holmes, M.A. (1997), Surface textural analysis of quartz sand grains from ODP Site 918 of the southeast coast of Greenland suggests glaciation of southern Greenland at $11 \mathrm{Ma}$, Paleogeography, Paleoclimatology, Paleoecology, 135: 109-121

Helland, P.E,, Huang, P.H., Diffendal, R.F. Jr (1997), SEM analysis of quartz sand grain surface textures indicates alluvial/colluvial origin of the Quaternary "glacial" boulder clays at Huangsham (Yellow Mountain), East-Central China, Ouaternary Research, 48: 177-186

Higgs R. (1979), Quartz-grain surface features of Mesozoic-Cenozoic sands from the Labrador and Western Greenland continental margins, Journal of Sedimentary Research, 49: 599-610.

Hoch, M., Koronko, B. (2007), Mikromorfologia powierzchni ziarn kwarcowych frakcji piaszczystej podlegajacych wietrzeniu mrozowemu wstęne wyniki badań [Micromorphology of quartz sand grain genetically connected with permafrost], in Solska, E., Giriat, D., (ed.), Rekonstrukcja dynamiki procesów geomorfologicznych - formy rzeźby i osady [Reconstruction of geomorhpological processes dynamics-forms of relief and deposits], Oficyna Wydawnicza Łośgraf, Warszawa: 217-232.

Klatkowa, H. (1976), Ślady środowiska eolicznego w rzeźbie powierzchni ziarn kwarcowych, wyniki analiz w elektronowym mikroskopie skaningowym [Tracks of aeolian conditions on the relief surface of the quartz-sand grains - results of the electron microscope study], Acta Geographica Lodzensia, 37: 93-108.

Kostrzewski, A. (1999), Funkcjonowanie geoekosystemów zlewni rzecznych. Powodzie rzek przymorza Battyku i innych regionów Polski : uwarunkowania, przebieg, skutki $w$ środowisku przyrodniczym [Functioning of catchment geoecosystems. River floods in the 
areas adjacent to Baltic Sea and in other regions of Poland: Conditioning, course, effects for the natural environment], Uniwersytet im. A. Mickiewicza w Poznaniu. Instytut Badań Czwartorzędu i Geoekologii. Zakład Geoekologii i Monitoringu Środowiska Przyrodniczego. Stacja Geoekologiczna w Storkowie.

Kowalkowski, A. (1984), Surface texture of quartz grains from tundra soils under electron microscope, Quaternary Studies in Poland, 5, Poznań: 75-79.

Kowalkowski, A. (1988a), Cechy urzeźbienia powierzchni ziarn piasku kwarcowego w kwaśnych $i$ alkalicznych glebach klimatu zimnego [Relief features of the surface of the quartz-sand grains in acid and alkaline soils of the cold climate], in Mycielska-Dowgiałło, E. (ed.), Geneza osadów i gleb $w$ świetle badań w mikroskopie elektronowym [Genesis of deposits and soils in light of the electron microscope research], Wydawnictwo Uniwersytetu Warszawskiego, Warszawa, 87-100.

Kowalkowski, A. (1988b), Procesy wietrzenia na Spitsbergenie na podstawie badań w mikroskopie elektronowym [Weather processes on Spitsbergen determined on the bases of electronic microscopy research], in Kostrzewski, A. (ed.) Geneza, Litologia i Stratygrafia Utworów Czwartorzędowych, Wydawnictwo Naukowe Uniwersytetu Adama Mickiewicza, Poznań, 15-27.

Kowalkowski, A., Brogowski, Z. (1983), Features of cryogenic environment of soils of continental tundra and arid steppe on the southern Khangai slope under the electron microscope, Catena, 10: 199-205.

Kowalkowski, A., Mycielska-Dowgiałło, E. (1980), Soil forming process in the tundra and arid steppe of the Khangai Mountains on the basis of quartz grains analysis with an electron microscope, Polish Journal of Soil Science, 13,1, Lublin: 59-63.

Kowalkowski, A., Mycielska-Dowgiało, E. (1983), The stratigraphy of fluvial and aeolian deposits in the Kopanica River Valley based on sedimentological and pedological investigations, Geologisches. Jahrbuch A71, Hannover: $119-148$.

Kowalkowski, A., Mycielska-Dowgiałło, E. (1988), Stratigraphie der fluviatilen und äolischen Sed- imente in Kopanica Tal auf Grund sedimentologischer und pedologischer Untersuchungen, Holocene Valley development-methods and results, Abstracts of Lectures, Symposium Franken, $25^{\text {th }}-30^{\text {th }}$ August, Düsseldorf: 35-37.

Kowalkowski, A., Kocoń, J. (1991), Procesy wietrzenia na Spitsbergenie na podstawie badań w skaningowym mikroskopie elektronowym [Weather processes on Spitsbergen determined on the bases of scanning electronic microscopy research], in Kostrzewski, A. (ed.), Geneza, Litologia i Stratygrafia Utworów Czwartorzędowych, Wydawnictwo UAM, Seria Geografia, 50, Poznań: 77-104.

Kowalkowski, A., Degórski, M. (2008), Wskaźniki dawnych i aktualnych środowisk kształtujących cechy teksturalne powierzchni ziarn piasku kwarcowego przy zastosowaniu skaningowej mikroskopii elektronowej [Indicators of former and current environments formative of the texture features of the surface of the quartz-sand grains at the use scanning electronic microscopy, Roczniki Gleboznawcze, 59, 3-4: 160-174.

Kozarski, S. (1972), Mikroskopia elektronowa w badaniu morfologicznych cech powierzchni kwarcowych ziarn piasku wybranych środowisk sedymentacyjnych [Electron microscopy in the study of quartz sand grains surface textures of selected sedimentary environments], Poznańskie Towarzystwo Przyjaciół Nauk, Wydział Matematyczno-Przyrodniczy, Prace Komisji Geograficzno-Geologicznej, 13(1): 179-189.

Kozarski, S. (1995), Deglacjacja północno-zachodniej Polski: warunki środowiska i transformacja geosystemu $(\sim 20 \mathrm{ka} \rightarrow 10 \mathrm{ka}$ BP [Deglaciation of Northeastern Poland, Environmental Conditions and Geosystem Transformation ( 20KA $\rightarrow 10 \mathrm{KA}$ BP.)], Dokumentacja Geograficzna 1, Instytut Geografii i Przestrzennego Zagospodarowania (IGiPZ), PAN, Wrocław: 9-82.

Krinsley, D.H., Doornkamp, J.C. (1973), Atlas of Quartz Sand Surface Textures, Cambridge University Press, Cambridge.

Mahaney, W.C. (1995), Pieistocene and Holocene glacier thicknesses and/or transport histories inferred from mierołextures and ąuartz particles, Boreas, 24: 293-304. 
Mahaney, WC. (2002), Atlas of sand grain surface textures and applications, Oxford University Press, Oxford.

Mahaney, W.C, Kaim, V. (1995), Scanning electron microscopy of Pieistocene tills in Estonia, Boreas, 24:13-29.

Margolis, S.W. Kennett, J.P. (1970), Antarctic glaciation during the tertiary recorded in sub-Antarctic deep Sea cores, Science, 170: 1085-1087.

Mycielska-Dowgiałło, E. (1963), Pomiary stopnia obtoczenia ziarn piasku i zastosowanie ich do badań geomorfologicznych [Measurement of the degree of grains sand abrasion and use their to geomorphologic research], Przeglad Geograficzny, 35, 1, Warszawa.

Mycielska-Dowgiałło, E. (1980), Cechy strukturalne i teksturalne osadów budujących formy eoliczne w rejonie Palmiry [Structure and texture feathers of sediments edifying eolian forms in the Palmiry region], Prace i Studia Geograficzne, 2, Warszawa.

Mycielska-Dowgiałło, E. (1988), Cechy urzeźbienia powierzchni ziaren kwarcu plaż różnych regionów klimatycznych świata [Relief features of the surface of the quartz grains of beaches in different climatic regions of the world, in Mycielska-Dowgiałło, E. (ed.), Geneza osadów $i$ gleb $w$ świetle badań $w$ mikroskopie elektronowym, Wydawnictwa Uniwersytetu Warszawskiego, Warszawa: 27-46.

Ribault, Le L. (1975), L'exoscopie, Méthode et application : Compagnie Francaise des Pe'troles, Notes et Memoires 12, Paris, 231 p.

Ribault, Le. L. (1977), L'exoscopie des quartz, Masson, Paris.

Riedl, R. (2000), Strukturen der Komplexitä: Eine Morphologie des Erkennens und Erklärens, Springer, Berlin.

Rose, K.C, Hart, J.K. (2008), Subgiacial comminution in the deforming bed: Inferences from SEM analysis, Sedimentary Geology 203: 87-97.

Scheidegger, A., Borkovec, M., and Sticher H. (1993) Coating of silica sand with goethite:
Preparation and analytical identification, Geoderma, 58, 43-65.

Schwamborn, G., Meyer, H., Fedorov, G., Schirrmeister, L., Hubberten, H.W. (2006), Ground ice and slope sediments archiving late Ouaternary paleoenvironment and paleoclimate signals at the margins - of El'gygytgyn Crater, NE Siberia, Quaternary Research, 66: 259-277.

Traczyk, A., Woronko, B. (2010), Historia zlodowacenia doliny Łomnicy w Karkonoszach w zapisie mikromorfologii powierzchni ziarn kwarcowych [History of glaciations of Łomnica Valley in the Karkonosze Mountains in recording of micro-morphology of quartz grain surface], Przeglad Geologiczny, $58,1-2 ; 1182-1191$.

Koronko, B., Ostrowska, M. (2009), Wpływ środowiska fluwialnego na charakter powierzchni ziarn kwarcowych - dyskusja [Impact of fluvial environment on the nature of quartz grain surface], in Kostrzewski A., Paluszkiewicz R (eds.) Geneza, Litologia i Stratygrafia Utworów Czwartorzędowych, Wydawnictwo Naukowe Uniwersytetu Adama Mickiewicza, Poznań, 5: 605-622.

Koronko, B., Bujak, Ł. (2010), Mikrorzeźba powierzchni ziaren kwarcowych frakcji piaszczystej osadów preglacjalnych serii kozienickiej jako wskaźnik warunków transportu i depozycji w południowej części Niziny Mazowieckiej [Micro-relief of quartz grains on sandy fraction of periglacial sediments of Kozienice series as an indicator of transport and deposition in the southern part of Masovia Lowland], Biuletyn Państwowego Instytutu Geologicznego 438, Państwowy Instytut Geologiczny, Warszawa, 137-154.

Paper first received: September 2011

In final form: November 2011 